\title{
Relationship between tourism sector and export: VAR analysis using Kazakhstan as case study
}

\author{
Nurkhodzha Akbulaev \\ Department of Economics and Business Administration, \\ Azerbaijan State University of Economics (UNEC) \\ Azerbaijan \\ nurboca@gmail.com

\section{Sudabe Salihova} \\ Department of Economics and Business Administration, \\ Azerbaijan State University of Economics (UNEC) \\ Azerbaijan \\ sudabe74@gmail.com
}

Abstract. Tourism is one of the increasingly dynamic sectors of the economy. In many countries, tourism plays an important role in the formation of gross domestic product, in activating foreign trade balance, in creating a lot of businesses and in employment. The contribution of tourism sector to the country's economy is difficult to calculate exactly because this sector is also, directly and indirectly, contributing to other sectors. Generally speaking, tourism always has a positive effect on economic growth. From the date of Kazakhstan independence declaration, tourism sector has always been given special importance. In Kazakhstan, tourism seems to have developed rapidly, especially after the declaration of independence, and is trying to gain its place in the international tourism. The aim of our work in this context is to test whether there is a relationship between tourism and export revenues and to identify the possible contributions of this sector to export-based economic growth. Thus, time series for the variables of tourism revenues and export revenues, between 1995 and 2015, were examined using the VAR model. The empirical results showed that both tourism revenues and export revenues have their impact on tourism revenues. In conclusion, tourism is a major sector of Kazakhstan's economy and it serves as a good source of foreign exchange. In this regard, investments in the aforesaid sphere of the country and the enactment of favourable policies lead to economic growth.

Keywords: Kazakhstan, economic growth, tourism revenues, causality analysis, VAR.

JEL Classification: C22, O40 


\section{INTRODUCTION}

Kazakhstan occupies an area of approximately 2.7 million square kilometres from the Caspian Sea in the West to China in the East, with the country's population being 16.4 million. Kazakhstan has demonstrated significant development in terms of tourism infrastructure, accommodation sector, accessibility and good relations with neighbouring countries. Kazakhstan has demonstrated some megatourism projects and has actively supported its image as an attractive, tourism-friendly and dynamically developing Eurasian country. The competitive advantage of Kazakhstan consists in tourism attractiveness of an exotic culture, recognizable image, natural environment, progressive business climate, as well as vast opportunities for sports and adventure. Educational, Scientific and Cultural Organization (UNESCO) World Heritage Sites are places of importance to our cultural heritage as described in the UNESCO World Heritage Convention, established in 1972. Kazakhstan accepted the convention on 29th April 1994, making its historical sites eligible for inclusion on the list. As at 2016, five sites in Kazakhstan were included as follow: Khoja Ahmed Yasawi Tomb, Petroglyphs within the Tamgaliye Archaeological Landscape, followed by Saryarka- Steppe and Lakes of Northern Kazakhstan. Two transnational properties, Silk Roads: the Routes Network of Chang'an-Tianshan Corridor and Western Tien-Shan (UNESCO, 2015).

Kazakhstan is recognized for its nomadic culture by the American and European tourism markets (Yessenova, 2014). The government treats tourism as one of the leading sectors in Kazakhstan's economy. Country's competitive advantage include: vast availability of labour skills, low electricity costs, modern airport infrastructure and attractiveness for foreign direct investments. Weaknesses consist of deficiency of advanced technical abilities, as well as security and peripheral sustainability (Baisakalova \& Garkevenko, 2014; Kantarci et al. 2015: 193). Nowadays, tourism in Kazakhstan is considered as a perspective direction in economic development beyond petrol and it has been included into seven clusters of national priorities (Porter, 2005). The State program of tourism development was improved during the year 2010-2015. Regional tourism development programs were adopted on the meso-level. Such kinds of programs were designed to promote the implementation of tourism projects which are of international standard: Jan-Ile, Aktau city, Kapshgay.

\section{LITERATURE REVIEW}

In many developing countries, the export-based development strategy forms the basic source of boost and economic growth. Especially, after 1960, a large number of less developed and developing countries' changing import substituting policies started to instigate their export and preferred exportbased growth as a policy. From literature review, a large number of surveys detailing the causality relationship between export and economic growth were found (Bahar, 2006, p.139). There exist similarities and differences of evidences obtained in empiric studies carried out on the subject of economic growth relationship with revenues from the tourism sector. The result showed that the economic growth of tourism was positively affected, in a general sense, the progress and increase in export led to relative growth with regard to this similarity and differences (Shan and Sun, 1998:1058-1060; Bahar, 2006, p.140). Furthermore, since economies of scale are applied, the connecting foreign exchange restrictions are reduced and the foreign exchange difficulties are lessened, positive externalities are provided in the sectors out of trade, the resources are effectively and profitably used to get competitive power, the investments are revived in traditional sectors and in the result, the export positively affects economic growth in accompaniment with increase in export of one country; (Mckinnon, 1964, pp.388409; Durbarry, 2004, pp.389-401; Bahar, 2006, p.140). From this point, there is need to express that 
theoretical reference which will cause economic growth of tourism as a strategy for development originates from literature of export and economic growth (Vanegas \& Croes, 2003, pp.315-330).

If we consider the empirical studies regarding this subject in literature, the increase of investment commodity with export-based growth model were indicated, the effects of economic growth of tourism sector with import of investment commodity were inspected in the same studies.

For instance, Nowak and Sahli (2008) indicated influences of these two variances on economic growth. These influences on Turkey, Tunisia, Morocco and Egypt were reviewed. In these studies, it was extrapolated that the international tourism behaviours (actions) have significant influence on the economic growth and progress of these countries. The same study was implemented by Nowak et al (2007). Following the study on Spain, they defend the hypothesis that increases export, import of investment commodity and affects positively the economic growth by this import. Meanwhile, the hypothesis of tourism-based growth in the study was tested.

It was concluded that there had been a significant relationship between tourism export, investment commodity import and economic growth in the result of studies following the rules of Johansen Cointegration Test and Granger Causality Test.

As observed in the above mentioned studies, tourism was generally accepted as an export item. For instance, tourism was approached as export by Kareem (2008). Using panel data management of tourism export for African countries, the influence - 692 III Interdisciplinary Tourism Researches Congress - on economic growth of these countries was analysed. At the end of the empirical study, we found out that tourism export led to economic growth. The influences of the commodity export and foreign exchange revenues on economic growth of Turkey were surveyed in the period of 1980-2005, Estimation (2006). The conclusion consists in the fact that the commodity export has positively and statistically reasonable influences on the development of Turkey, but it has no significant impact on growth of tourism revenue in the study applying the Ordinary Least Squares. It was carried out by Kizllgol (2006) in other studies who tested the hypothesis on export and tourism based growth for Turkey. These hypotheses were tested by the aid of GSYIH within the period of 1963-2005, a co-integration analysis was carried out with data of export and tourism revenues, even by correction model and Granger causality test. From the study, the long-term relationship between export revenues, tourism incomes and growth was found. It was observed that these two hypotheses had been accessible to Turkey.

Using monthly data within the year 2003-2012, it was analysed by applying the time -series econometric techniques of dynamic relationships between growths, export and tourism revenues in Turkey. The causality towards the growth of export and tourism revenues and towards export from tourism revenues by this growth was discussed in a long-term period according to the test results of Granger causality. Whereas in a short-term period, there is causality from tourism revenues towards export by growth and from growth toward tourism revenues. The result of impulse -response and variance decomposition (separation) analysis also support findings from Granger causality test.

Due to these consequences, there appeared unilateral causality from economic growth towards tourism revenues (Kizilgol \& Erbaykal, 2008). In this study, the causality relationship between economic growth accompanying tourism incomes, considered as one of the most important income items for Turkey was surveyed in Toda-Yamamoto management framework by using three-month tourism incomes and GDP referring to 1992:01-2006:02 periods. Contrary to studies in literature for Turkey, the results showed that the direction of causality led to increase in economic growth and higher income from tourism. By this result, there is need to attain a steady and executable growth rate of Turkey in order to get more tourism incomes.

The effect of export and tourism incomes for Turkey was analysed in this study by means of cointegration and causality analysis using annual data set with respect to export revenues and tourism 
incomes as well as gross national product from 1969-2009. According to the results of Johansen cointegration test, it was concluded that a long-term relationship exist between the export revenues, tourism incomes and economic growth. Moreover, the causality analysis based on error correction model showed that there existed only unilateral causality from export and tourism incomes towards economic growth.

The hypothesis of long-term growth based on export and tourism can be considered valid. It is observed that the rises in export tourism incomes increased GNP for a long period. When the calculated flexibility effect is interpreted, a rise of $1 \%$ in export revenues increases GNP nearly in amount by $\% 0.16$, a rise of $\% 1$ in tourism incomes increases GNP nearly in amount by \%0.10. Export and tourism series verify theoretical expectations in positive connection with GNP series.

\section{METHODOLOGY}

The main aim of the study was to test long-term relationship between tourism incomes and export, and to make possible contributions for this sector relating it to export. In conclusion, the hypothesis "there is positive impact of tourism incomes on export" will be tested by this study.

In this study, it makes more difference than in other studies from the point of view of the created model approximation and the applied tests. Starting from this point, the superiority of relationship between two series will be dimensioned using the export (y) time series with those of tourism incomes (x). Statistical data from 1995-2015 regarding the said two variances were reached by databases of the Ministry of Tourism of the Republic of Azerbaijan, State Statistic Committee, Central Bank of the Republic of Azerbaijan and World Bank and all variances were expressed as natural logarithms. While measuring relationship between the aforesaid two series, VAR method will be used. Impulse - response function and variance decomposition results for approximated VAR model will be determined.

It is necessary to indicate the time series that will primarily be analysed, regression technique is used if stagnant in revealing the relationships between variances in the model. Otherwise, it may not be possible to advance a model conforming to the used time series and to make a prediction (Kutlar, 2000, 1-13.).

There is one thing that should be expressed by the stationarity; this requires the statistic priorities of time series not to be changed with time. Stated in other words, the average and variance of series have stable or long-term trend to average. (Engle \& Granger, 1987, pp.987-1007; Bahar, 2006, p.140). Generally, it is clear that time series belonging to various variances related to the economy are not stable or stagnant. Stability of series is broken by virtue of trend, seasonal effects and random causes. In this sense, unit root tests are easy to comprehend whether or not the series are stable.

A great amount of macroeconomic time series contain unit roots. Unit root tests are significant in the survey of stationarity of one-time series. This is why existence of unstable regressor makes the several standard hypothesis test invalid. In other words, regression analyses in unstable series causes high test statistics and false regression. Both tourism incomes and EXPORT variances were deemed as stable trend in stationarity test.

As shown in Table 1, ADF test results applied for level grade of variances showed their state of stability. This feature is important for VAR analysis. 
Table 1

Results of unit root test

\begin{tabular}{|c|c|c|c|c|c|}
\hline \multicolumn{6}{|c|}{ Test Statistics (in grade) } \\
\hline \multicolumn{6}{|c|}{ Ho. It exists as unit root } \\
\hline \multirow[t]{2}{*}{ Variances } & \multirow[t]{2}{*}{ Tests } & \multicolumn{2}{|c|}{ Constant } & \multicolumn{2}{|c|}{ Constant and trend } \\
\hline & & t-statistics & p-value & t-statistics & p-value \\
\hline \multirow[b]{2}{*}{ LN(İHR) } & $\mathrm{ADF}$ & $-3.9219 *$ & 0.0079 & -7.7220 & 0.07032 \\
\hline & P-p & $-7.3394 *$ & 0.0000 & -1.6817 & 0.7214 \\
\hline \multirow[b]{2}{*}{ LN(TG) } & $\mathrm{ADF}$ & $-3.2580^{*}$ & 0.0313 & 3.5130 & 0.0651 \\
\hline & P-p & $-3.3409^{*}$ & 0.0265 & -3.4755 & 0.0697 \\
\hline
\end{tabular}

Note: $*$ No hypothesis is rejected. Unit root does not exist. (at $5 \%$ significant level)

\section{VAR Model}

VAR model covers all selected economic superiorities as an integral part. If it should be said more clearly, variances or superiorities in econometric studies are simultaneously surveyed using the aforesaid model. Similar to theoretical models, a categorical decomposition of intrinsic and extrinsic variances doesn't exist. This does not allow for break model definition of constraints and suppositions put forward by economic theory. Similarly, no pre-restriction has been made on relationships between variances. Thereby, the adverse effects of presuppositions which the economists have to make in the phase of model setup are eliminated to a large extent. Statistic and econometric tests of various hypotheses put forward by economic theory were realized using numerical economic data (Ozgen \& Guloglu, 2004, pp.93-114.). VAR analysis carried out without these economic constraints yielded results better than classical structural modelling. This makes fictionalizing possible or help in amending the existing relationship between two variances in the VAR model. Being both intrinsic and extrinsic, they could not be implemented (Bahar, 2006, p.143).

The conducted regression results are issued in the following equations;

$$
\begin{aligned}
& \Delta y_{t}=\alpha_{1}+\sum_{p}^{k} \beta_{1 p} \Delta x_{t-p}+\sum_{p}^{k} \gamma_{1 p} \Delta y_{t-p}+\varepsilon_{1 t} \\
& \Delta x_{t}=\alpha_{1}+\sum_{p}^{k} \delta_{2 p} \Delta y_{t-p}+\sum_{p}^{k} \beta_{2 p} \Delta x_{t-p}+\varepsilon_{2 t}
\end{aligned}
$$

VAR model with two variances are expressed as shown above in Eq. 1 and 2. In this model: y denotes $\operatorname{Ln}(\dot{\mathrm{I} H R}), x$ expresses tourism incomes $(\operatorname{Ln}(\mathrm{TG}))$. P indicates lags length, $\varepsilon$ shows that the average is zero, co-variances is zero with its lagging estimations and variances being constant, and random error terms are having normal distribution.

Error terms are not correlated with all intrinsic and extrinsic variances. It is impossible to encounter problems simultaneously because only the lag estimations of intrinsic variances are in the right side of the model. Every equation under these circumstances can be envisaged using the least squares method (Greene, 1993; Bahar, 2006, p.143).

The lag length is 1 following a great deal of criteria ( 5 criteria) as shown in Table 2 in the analysis implemented to determine the related lag length of its model. 
Determination of the related Lag Length

\begin{tabular}{|c|c|c|}
\hline & $\mathrm{y}$ & $\mathrm{x}$ \\
\hline & 0.805429 & 0.157504 \\
$\mathrm{Y}(-1)$ & $(0.16225)$ & $(0.06398)$ \\
& {$[4.96411]$} & {$[2.46168]$} \\
\hline \multirow{2}{*}{$\mathrm{X}(-1)$} & 0.172479 & 0.414241 \\
& $(0.46309)$ & $(0.18262)$ \\
& {$[0.37245]$} & {$[2.26835]$} \\
\hline $\mathrm{C}$ & 1.120359 & 8.563256 \\
& $(5.97662)$ & $(2.35683)$ \\
\hline
\end{tabular}

Note: ${ }^{*}$ this indicates a quantity of the related lag for the relevant criteria

We speculate or approximate VAR (1) intending 1 lag.

\section{EMPIRICAL RESULTS AND DISCUSSION}

The related lag length of the approximated model was attained as one in this study. Inverse roots of AR characteristic polynomial indicated in Graphics 1 were observed in unit circle. It means that the whole model is stable.

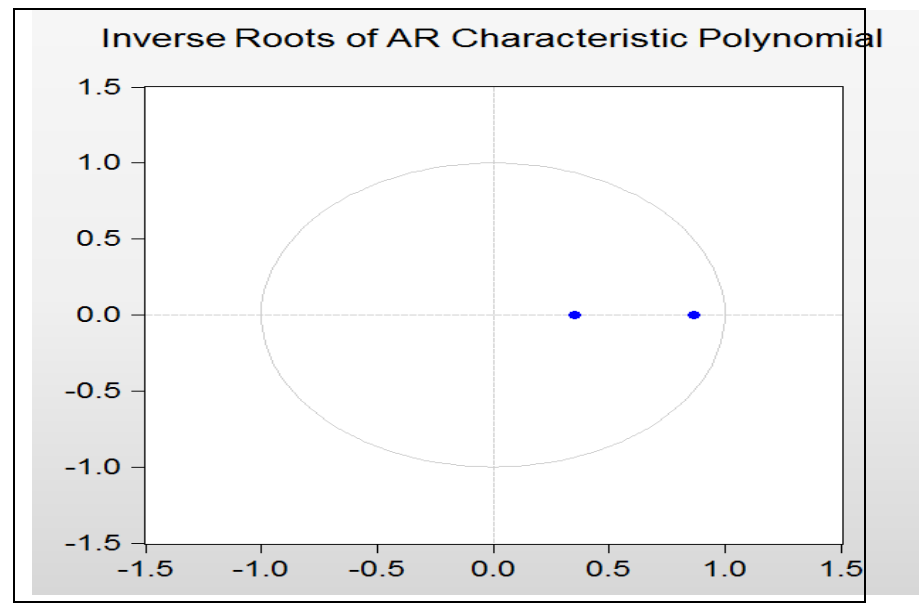

Graphics 1. Inverse roots of characteristic polynomial

There are no autocorrelation problem according to the Autocorrelation LM Test applied for the purpose of testing whether the error terms of model are correlated (Table 3).

Table 3

Autocorrelation test

\begin{tabular}{|c|c|c|}
\hline Lags & LM-Stat & Prob-Value \\
\hline 1 & 8.175 & $\mathbf{0 . 4 6 5 3}$ \\
\hline 2 & 10.171 & $\mathbf{0 . 7 6 7 4}$ \\
\hline 3 & 17.791 & $\mathbf{0 . 5 1 7 8}$ \\
\hline
\end{tabular}

Furthermore, as shown in the table, we were not faced with the problem of changing variance (heteroscedasticity) in the model due to the results of White Test applied, which tested whether it was constant for all samples of error term variance. 
White test result

VAR Residual Heteroskedasticity Test: No Cross Terms (only levels and squares)

Date: 02/05/2018

Sample: 19952015

Include observations: 20

\begin{tabular}{|c|c|c|}
\hline Join test: & \multicolumn{2}{|l|}{} \\
\hline Chi-sq & df & Prob \\
\hline 16.65453 & 12 & 0.1631 \\
\hline
\end{tabular}

\begin{tabular}{|c|c|c|c|c|c|}
\hline \multicolumn{7}{|c|}{ Individual components: } \\
\hline Dependent & R-squared & $\mathrm{F}(4,15)$ & Prob. & Chi-sq(4) & Prob. \\
\hline res1*res1 & 0.185116 & 0.851883 & 0.5144 & 3.702324 & 0.4478 \\
\hline res2*res2 & 0.267203 & 1.367377 & 0.2918 & 5.344055 & 0.2538 \\
\hline res2*res1 & 0.185845 & 0.856000 & 0.5122 & 3.716891 & 0.4457 \\
\hline
\end{tabular}

Consequently, the conducted tests proved that structurally, there had not been any problem of VAR model approximated in the study.

After testing for provision of stable conditions, the Impulse-Response analysis can be implemented. Impulse - Response Functions showed the impulse or effect of one standard deviation shock detected by VAR analysis in one of the random error terms on both present and future values of endogenous shock. The following impulse-response functions resulted using the method of "Cholosky decomposition".

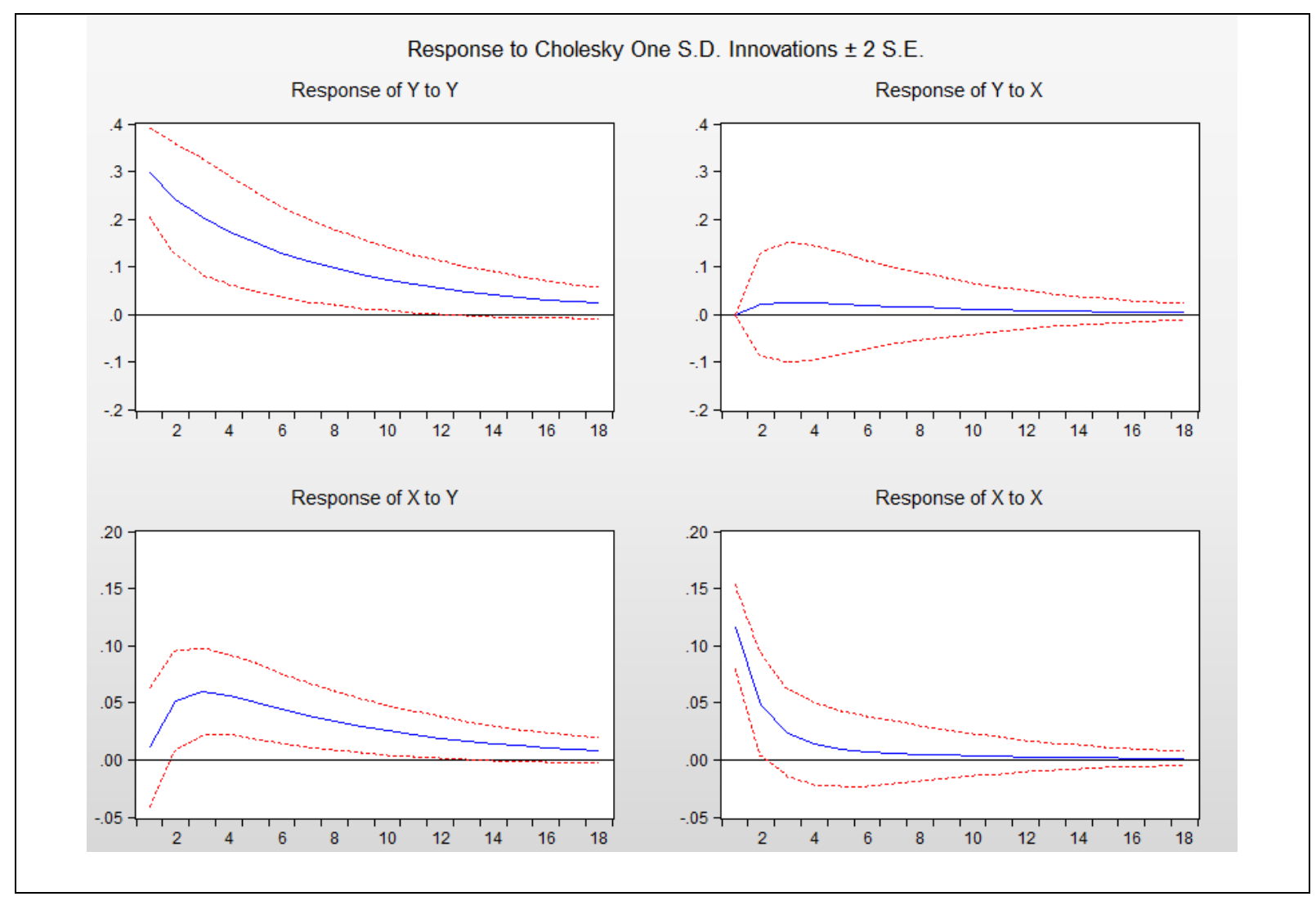

Graphics 2. Impulse-response functions 
Explanation: While horizontal axle of graphics indicate direction and superiority of impulse of other variance given to other one-unit, the positive shock related to the relevant variance, after shocking the vertical axle, showed the last 18 months-duration. While straight lines indicate the pint estimation, the dotted / dashed lines represent the \pm 2 standard deviation confidence intervals for impulses by variances.

The situation in the impulse - response graphics indicated in the Figure, which drew our attention, became balanced against the shocks of tourism incomes. It emerged both in themselves and in export within a period of 18 days. Beyond this situation, 0.297081 unit reacted with one standard deviation shocking that emerges in tourism incomes of export. This impulse reached 0.059331 unit which increased in the first three periods, then gradually, it descended but not balanced. Tourism incomes react or give an impulse on the unit of 0.116598 on one standard deviation shocking that emerges on its own. Even this impulse falls down rapidly in the first three periods, thereafter, the speed continued to decrease and became balanced. While the tourism incomes failed to impulse on one standard deviation shock, unit of 0.020111 is impulsed in the second period. This impulse demonstrated the small impulse till the fifth period and then became balanced as it gradually decreased.

Table $5 \mathrm{a}$

Results of variance decomposition

\begin{tabular}{|c|c|c|c|}
\hline Variance Decomposition of Y: \\
\hline Period & S.E. & Y & X \\
\hline 1 & 0.297081 & 100.0000 & 0.000000 \\
\hline 2 & 0.383221 & 99.72461 & 0.275393 \\
\hline 3 & 0.434447 & 99.46696 & 0.533038 \\
\hline 4 & 0.468555 & 99.28475 & 0.715249 \\
\hline 5 & 0.492389 & 99.16248 & 0.837519 \\
\hline 6 & 0.509466 & 99.08026 & 0.919742 \\
\hline 7 & 0.521880 & 99.02401 & 0.975988 \\
\hline 8 & 0.530986 & 98.98480 & 1.015203 \\
\hline 9 & 0.537707 & 98.95699 & 1.043008 \\
\hline 10 & 0.542688 & 98.93701 & 1.062990 \\
\hline 11 & 0.546391 & 98.92250 & 1.077503 \\
\hline
\end{tabular}

From the table above, $100 \%$ of change in the first period of export were self-originated, $99.72 \%$ from itself and $0.28 \%$ from change in tourism incomes in the second period. Approximately, $1.1 \%$ of changes originated from change in tourism incomes and $98.9 \%$ from export itself.

From the table above, $99 \%$ of change in the first period of tourism incomes originated from self and $1 \%$ from export. In the 2 nd period, $85 \%$ was derived from itself and 15\% from change in export. Approximately, $54 \%$ of changes were derived from change in export, while 46 percentage of change was obtained from change in tourism incomes.

In Table 6, the results of Granger causality test to define whether there is a relationship between tourism incomes and export are presented, and direction of relationship if available: 
Results of variance decomposition

\begin{tabular}{|c|c|c|c|}
\hline Variance Decomposition of X: & \multicolumn{2}{|l|}{ Y } \\
\hline Period & S.E. & 0.942744 & 99.05726 \\
\hline 1 & 0.117151 & 14.86899 & 85.13101 \\
\hline 2 & 0.136784 & 27.68080 & 72.31920 \\
\hline 3 & 0.150888 & 36.34226 & 63.65774 \\
\hline 4 & 0.161708 & 41.93857 & 58.06143 \\
\hline 5 & 0.169763 & 45.61748 & 54.38252 \\
\hline 6 & 0.175686 & 48.10364 & 51.89636 \\
\hline 7 & 0.180036 & 49.82613 & 50.17387 \\
\hline 8 & 0.183240 & 51.04338 & 48.95662 \\
\hline 9 & 0.185608 & 51.91661 & 48.08339 \\
\hline 10 & 0.187364 & 52.91661 & 47.44989 \\
\hline 11 & 0.188669 & 53.01353 & 46.98647 \\
\hline 12 & 0.189642 & 53.35462 & 46.64538 \\
\hline 13 & 0.190367 & 53.60682 & 46.39318 \\
\hline 14 & 0.190909 & 53.79393 & 46.20607 \\
\hline 16 & 0.191314 & 53.93310 & 46.06690 \\
\hline 17 & 0.191616 & 54.03680 & 45.96320 \\
\hline 18 & 0.191843 & 54.11418 & 45.88582 \\
\hline
\end{tabular}

Table 6

Granger Causality Test Results

\begin{tabular}{|c|c|c|c|}
\hline \multicolumn{4}{|l|}{$\begin{array}{l}\text { Data period:1995-2015 } \\
\text { Lag length: } 1 \text { ( for SC) }\end{array}$} \\
\hline $\mathrm{H}_{0}$ Hypothesis & Data & F value & Possibility \\
\hline & & 0.13872 & 0.7142 \\
\hline It is not Granger cause of $\mathrm{Y}, \mathrm{X}$. & & 6.05988 & $0.0248^{*}$ \\
\hline
\end{tabular}

The zero hypotheses "Tourism incomes are not Granger cause of export revenues" was adopted in Table 9. While the hypothesis "export revenues are not Granger cause" being rejected at 5\% significance level, the alternative hypothesis "Export revenues are Granger cause of tourism incomes" was adopted. In a way, the export revenues influenced tourism incomes. Thereby, unilateral relationship exist between export revenues and tourism incomes (Export revenues $\rightarrow$ Tourism incomes).

\section{CONCLUSION}

The Tourism sector became the focus of many countries for both provision of new work places and earning of foreign exchange. Therefore, the influence of income on Kazakhstan tourism being essential in world tourism, which was obtained from the realization of international tourism, on export in Kazakhstan was explored in this study. Using statistical data covering the years 1995-2015 in this study, it was tested whether there exists the dynamic and causal relationship between tourism incomes and export revenues.

Granger causality test applied in the study, showed a unilateral relationship between export revenues and tourism revenues. On the other hand, it has been shown from the VAR analysis that the lag estimations of export and tourism revenues influence each other to a reasonable extent. From the results of impulse-response analysis, as variances of the export and tourism revenues react against shock of a standard deviation for 18 days, a shock of one standard deviation emerging from export revenues and a shock of one standard deviation emerging from tourism incomes considerably influenced export. 
Separately, tourism revenues are being balanced against the shocks arising from both themselves and from exports over a period of 18 days. A 100\% of the change in the first period of export according to results of variance decompositions belonging to variances in the installed VAR model originates from itself, but in the upcoming periods, $98.9 \%$ originates from itself and approximately $1.1 \%$ arise from changes in tourism revenues. In a similar manner, $99 \%$ of the changes in the first period of tourism revenues is derived from itself, but in forthcoming periods, $46 \%$ originates from self and $54 \%$ from changes in export.

Consequently, tourism is a major sector that provides an important foreign exchange inflow for Kazakhstan. In this regard, investments in the aforesaid sphere of the country lead to economic growth by the enactment of favourable policies.

\section{REFERENCES}

Adrian, C., \& Darnell, A. (1990). Dictionary of Econometrics, England: Edward Elgar Publications.

Aktas, A.R., Kaplan, F., \& Kocaman, S. (2013). Relationship between tourism and economic growth: a panel data analysis on mediterranean countries. International Conference on Eurasian Economies 2013, SESSION 5C: Turizm II, 755-760.

Anbao, T., \& Danhua, Z. (2011). A comparative analysis on the factors promoting China's economic growth based on demand. Energy Procedia, 5, 1388-1393.

Arslanturk, Y., Balcilar, M., \& Ozdemir, Z. A. (2011). Time-varying linkages between tourism receipts and economic growth in a small open economy. Economic Modelling, 28(1-2), 664-671.

Atukeren, E. (2011). Granger-New Approaches to Causality Tests. Ataturk University. FEAS Journal, 10th Econometrics and Statistics Symposium Special Issue, 137-153.

Awokuse, T. O., \& Christopoulos, D. K. (2009). Nonlinear dynamics and the exports-output growth nexus. Economic Modelling, 26(1), 184-190.

Bahar, O. (2006). Turkey's impact on the economic growth of the tourism sector: VAR analysis approach. Management and Economics: Celal Bayar University Faculty of Economics and Administrative Sciences Journal, 13(2), $137-$ 150.

Baisakalova, A., \& Garkavenko, V. (2014). Competitiveness of Tourism Industry in Kazakhstan, 15-40, in Tourism in Central Asia: Cultural Potential and Challenges, Kantarci, K., Uysal, M., and Magnini, V., (Eds), Apple Academic Press, Canada; Francis \& Taylor Group.

Başaran, M. A. (2016). Kemal Kantarci, Muzaffer Uysal, Vincent Magnini \&. The Routledge Handbook of Tourism in Asia, 275.

Chen, C. F., \& Chiou-Wei, S. Z. (2009). Tourism expansion, tourism uncertainty and economic growth: New evidence from Taiwan and Korea. Tourism Management, 30(6), 812-818.

Choban, O., \& Özcan, C.C. (2013). Turkey Tourism Revenues in the international peer-Economic Growth Relationship: Causality Analysis (1963-2010). Eskisehir Osmangaz̨i University Faculty of Economics Journal, 8(1), 243-261.

Cortes-Jimenez, I., Pulina, M., Prunere, C. R., \& Artis, M. (2009). Tourism and exports as a means growth. Research Institue of Apllied Economics, 10, 1-26.

Deger, M. K. (2006). Backed Tourism and Export Growth: 1980-2005 Experience of Turkey. Atatürk University Journal of Economics and Administrative Sciences, 20(2), 67-86.

Durbarry, R. (2004). Tourism and economic growth: the case of Mauritius. Tourism Economics, 10(4), 389-401.

Engle, R. F., \& Granger, C. W. (1987). Co-integration and error correction: representation, estimation, and testing. Econometrica: journal of the Econometric Society, 55(2), 271-276.

Engle, R., \& Granger, J. (1987). Cointegration and error correction: representation, estimation and testing, Econometrica, 50, 987-1007. 
Espenbetov, N, Sardarov, O., Pestova, A., Ushkulakova, G., \& Imangulova, T. (2017). The characteristic features of the development of tourism in the mountainous regions of Kazakhstan Los rasgoscaracterísticos del desarrollodel turismo en las regionesmontañosas de Kazajstán, Revista ESPACIOS, 38 ( ${ }^{\circ}$ 47), 36.

Granger, C. W. (1969). Investigating causal relations by econometric models and cross-spectral methods. Econometrica: journal of the Econometric Society, 424-438.

Greene, W.H. (1993). Econometric Analiysis, Second Edition. Prentice-Hall.

He, D., \& Zhang, W. (2010). How dependent is the Chinese economy on exports and in what sense has its growth been export-led?. Journal of Asian Economics, 21(1), 87-104.

Kantarci, K., Başaran, M. A., \& Özyurt, P. M. (2017). Comparative analysis of Central Asian tourism product from point of view of Turkish travelers: A case of Kyrgyzstan, Kazakhstan, Tajikistan, Uzbekistan and Turkmenistan. Eurasian Economies in Transition, 339-357.

Kareem, O. I. (2008). Tourism- Exports and Economic Growth in Africa. 13 th African Econometrics Society Confrence, (p. 1-31).

Kizilgol, O. (2006). Was based on exports and tourism in Turkey growth testing: Cointegration and causality, Academic Perspective. International Refereed Social Science E-Journal, 10, 1-19.

Kızılgöl, Ö., \& Veerbaykal, E. (2008). Tourism revenue in economic growth relations with Turkey: A causality analysis. Süleyman Demirel University Faculty of Economics and Administrative Sciences Journal, 13, 351-360.

Kusluvan, S., \& Kusluvan, Z. (2000). Perceptions and attitudes of undergraduate tourism students towards working in the tourism industry in Turkey. Tourism Management, 21(3), 251-269.

Kutlar, A. (2000). Ekonometrik Zaman Serileri. Ankara: Gazi Kitapevi, 1-13.

Lee, C. C., \& Chang, C. P. (2008). Tourism development and economic growth: A closer look at panels. Tourism management, 29(1), 180-192.

Lee, C. C., \& Chien, M. S. (2008). Structural breaks, tourism development, and economic growth: Evidence from Taiwan. Mathematics and Computers in Simulation, 77(4), 358-368.

Love, J., \& Chandra, R. (2005). Testing export-led growth in Bangladesh in a multivarate VAR framework. Journal of Asian Economics, 15(6), 1155-1168.

Marcouiller, D. W., Kim, K. K., \& Deller, S. C. (2004). Natural amenities, tourism and income distribution. Annals of Tourism Research, 31(4), 1031-1050.

Marin, D. (1992). Is the export-led growth hypothesis valid for industrialized countries?. The Review of Economics and Statistics, 74(4): 678-688.

McKinnon, R. I. (1964). Foreign exchange constraints in economic development and efficient aid allocation. The Economic Journal, 74(294), 388-409.

Moosa, I. A., \& Choe, C. (1998). Is the Korean economy export-driven?. Economic Modelling, 15(2), 237-255.

Nazarbaev, N. (2009). The decree of the President of the Republic of Kazakhstan "About implementation of the Tashkent declaration of heads of the Turkish speaking states, the project of UNESCO and the World Tourism Organization on tourism infrastructure development on the Great Silk way in the Republic of Kazakhstan", N 3476.

Nazarbaev, N. (2009). The decree of the President of the Republic of Kazakhstan "About the State program of the Republic of Kazakhstan "Revival of the historical centers of the Silk way, preservation and successive development of a cultural heritage of the Turkic-speaking states, tourism infrastructure creation", N 3859.

Nowak, J. J., \& Sahli, M. (2008, February). Tourism, capital good imports and long-run growth. In Economic Research Forum Working Papers (No. 382).

Nowak, J. J., Sahli, M., \& Cortés-Jiménez, I. (2007). Tourism, capital good imports and economic growth: theory and evidence for Spain. Tourism Economics, 13(4), 515-536.

Oh, C. O. (2005). The contribution of tourism development to economic growth in the Korean economy. Tourism management, 26(1), 39-44.

Özcan, B., \& Özçelebi, O. (2013). İhracata Dayalı Büyüme Hipotezi Türkiye İçin Geçerli Mi?. Yönetim ve Ekonomi: Celal Bayar Üniversitesi İktisadi ve İdari Bilimler Fakültesi Dergisi, 20(1), 1-14.

Ozer, M., \& Erdogan, L. (2006). In Turkey export, import and time-series analysis of the relationship between economic growth. Gazi University Economic Approach, 17, 93-110. 
Ozer, M., \& Kirca, M. (2014). Time series analysis of relationships between tourism income, exports and economic growth. III. Interdisciplinary Tourism Research Congress, pp. 684-707, April 04-05, Kushadasi, Aydın.

Ozgen, F. B., \& Guloglu, B. (2004). Analysis of economic effects of domestic debt in Turkey using VAR technique. METU Studies in Development, 31, 93-114.

Polat, E., \& Gunay, S. (2012). Turkey in tourism and export revenues of economic growth test of impact on cointegration and causality analysis. Süleyman Demirel University Journal of the Institute of Science and Technology, 16(2), 204-211.

Porter, M. E. (2004). Competitive Advantage. Free Press: New York.

Porter, M. E., (2005). Kazakhstan's competitiveness: Roadmap towards a diversified economy. Institute for Strategy and Competitiveness. $\quad$ Retrieved May 14, from http://www.hbs.edu/faculty/Publication\%20Files/Kazakhstan Competitiveness 2005. $01.26 \quad 35321255-$ da68-4cb9-a97b-1cba5f2535f5.pdf.

Sadorsky, P. (2012). Energy consumption, output and trade in South America. Energy Economics, 34(2), 476-488.

Salihova, S., \& Akbulaev, N. (2014). Azerbaijan's tourism sector impact on economic growth: VAR analysis approach. 1st International Congress of Tourism and Management Studies, 09-11 May 2014, Istanbul / Turkey. pp.626-639.

Sandalcilar, A. R. (2012). Relations between Turkey and paper consumption and economic growth: Cointegration and causality analysis. CU Journal of Economic and Administrative Sciences, 13(2), 1-15.

Schubert, S. F., Brida, J. G., \& Risso, W. A. (2011). The impacts of international tourism demand on economic growth of small economies dependent on tourism. Tourism Management, 32(2), 377-385.

Shan, J., \& Sun, F. (1998). On the export-led growth hypothesis: the econometric evidence from China. Applied Economics, 30(8), 1055-1065.

Sr, M. V., \& Croes, R. R. (2003). Growth, development and tourism in a small economy: Evidence from Aruba. International journal of tourism research, 5(5), 315-330.

Tang, C. F., \& Tan, E. C. (2013). How stable is the tourism-led growth hypothesis in Malaysia? Evidence from disaggregated tourism markets. Tourism Management, 37, 52-57.

Tang, C. H. H., \& Jang, S. S. (2009). The tourism-economy causality in the United States: A sub-industry level examination. Tourism Management, 30(4), 553-558.

Tekin, R. B. (2012). Economic growth, exports and foreign direct investment in Least Developed Countries: A panel Granger causality analysis. Economic modelling, 29(3), 868-878.

Temiz Clean, D. (2008). Income tax and economic growth relationship in Turkey: 1960-2006 period. 2nd National Economic Congress / 20 to 22 February 2008 / Dokuz Eylul University Faculty of Economics Department of Economics / Izmir-Turkey, pp. 1-18.

Temiz, D., \& Gökmen, A. (2010). An analysis of the export and economic growth in Turkey over the period of 1950-2009. International Journal of Economic and Administrative Studies, 3(5), 123-142.

TIKA Kyrgyzstan Country Report. (1996). Ankara, 1996.

Tiwari, A. (2011). Tourism, Exports and FDI as a Means of Growth: Evidence from four Asian Countries. Romanian Economic Journal, 14(40) 131-151.

UNESCO. (2015). Retrieved June 20 2015, from http://whc.unesco.org/en

UNWTO. (2015). Tourism Highlights. Retrieved June 20 2015, from, http://dtxtq4w60xqpw.cloudfront.net/sites/all/files/pdf/unwto_highlights14_en_hr_0.pdf

Yessenova, S. (2014). Cinema as branding, 173-200, in tourism in Central Asia: Cultural potential and challenges. Kantarci, K., Uysal, M. and Magnini, V. (Eds). Apple Academic Press, Canada; Francis \& Taylor Group. 